\title{
A Ratiometric Fluorescent Viscosity Sensor
}

Mark A. Haidekker, ${ }^{\mathrm{a}^{*}}$ Thomas P. Brady, ${ }^{\mathrm{b}}$ Darcy Lichlyter ${ }^{\mathrm{a}}$ and Emmanuel A. Theodorakis $^{\mathrm{b}^{\mathrm{*}}}$

${ }^{a}$ Department of Biological Engineering, University of Missouri-Columbia, Columbia, MO 65211 and

${ }^{b}$ Department of Chemistry and Biochemistry, University of California, San Diego, 9500 Gilman Drive, La Jolla, CA 92093-0358

\section{Supporting Information}

Table of Contents

1. Supplemental data Page

2. General Techniques $2-4$

3. Key experimental procedures/data

5

4. NMR Spectra

8-15 


\section{Supplemental Results}

Design of the ratiometric probe: The linker length was dictated by the requirements for an energy transfer system. Our goal was to provide considerable energy transfer to the acceptor (rotor) unit, while still obtaining measurable emission from the donor (reference). Energy transfer efficiency $\mathrm{E}$ depends on the chromophore distance $\mathrm{r}$ and the Förster distance $\mathrm{R}_{0}$ (a dye-dye constant) according to $E=r^{6} /\left(r^{6}+R_{0}^{6}\right)$. We determined the Förster distance to be $30 \AA$, indicating a preferentially short linker for $r \cong R 0$. The above considerations prompted the synthesis and study of dye $\mathbf{4}$ in which the calculated distance $r$ between the fluorescent units is approximately $26 \AA$ (measured between the atoms shown below).

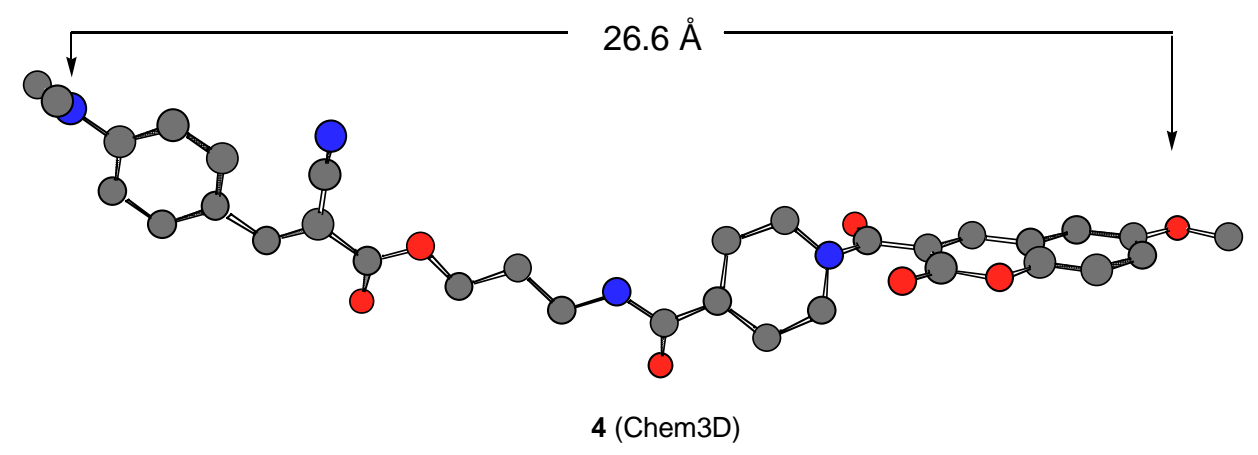

Resonance energy transfer: Covalent linking of the dyes is essential to elicit resonance energy transfer (RET). RET allows the quick acquisition of simultaneous ratiometric data with a single excitation source. A comparison of the emission spectra of a solution of both unlinked individual dyes to the emission spectra of the covalently linked dye $\mathbf{4}$ can be seen in Figure S1. In a solution of unlinked dyes, the average distance of the dyes is too big for efficient RET. 

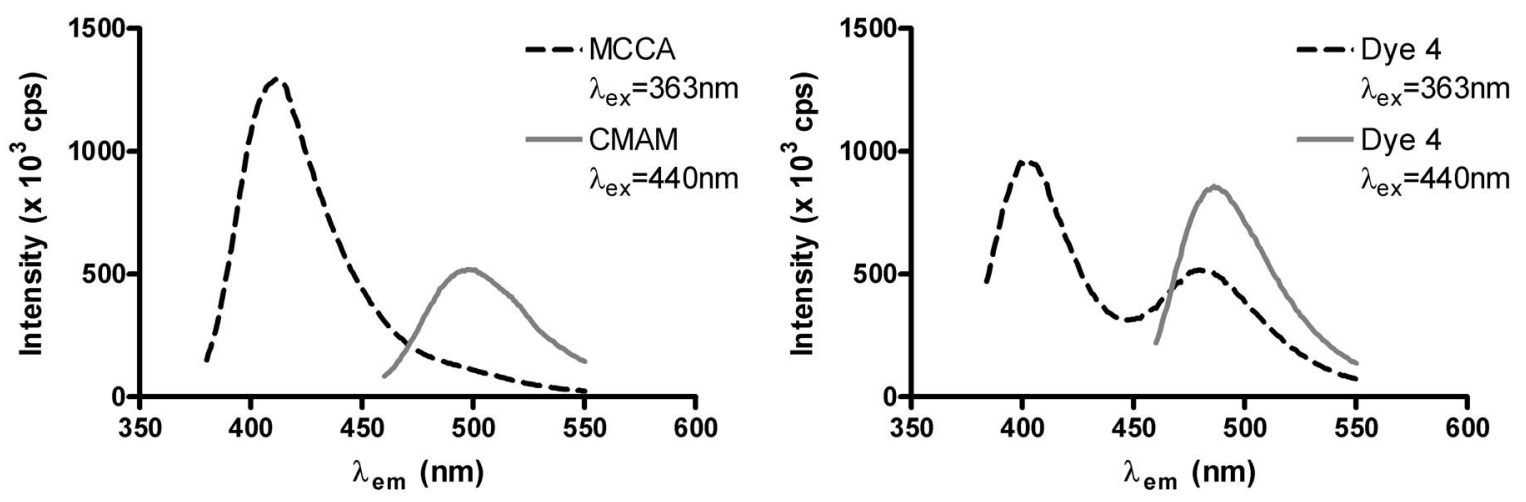

Figure S1: Comparison of emission spectra of a solution of $10 \mu \mathrm{M}$ MCCA and CMAM in ethylene glycol (left) and dye 4 (CMAM and MCCA covalently linked) in ethylene glycol. In the first case, no RET can be seen. In the second case, RET leads to a reduction of the primary MCCA emission peak, while at the same time a secondary emission peak (CMAM group excited through RET) can be observed.

Stability of 4 in biofluids: Dye 4 was exposed to human blood plasma for 2 hours. Peak emission intensities of both constituents, simultaneously excited at 360nm, was acquired. Figure $\mathrm{S} 2$ shows the emission intensity over time. Cleavage would disrupt RET and lead to a dramatic increase of the CMAM peak at $495 \mathrm{~nm}$ combined with a marked increase of the MCCA peak at $435 \mathrm{~nm}$ as seen in Figure 1 (main text). The observed data does not show these effects, allowing the conclusion that cleavage does not take place.

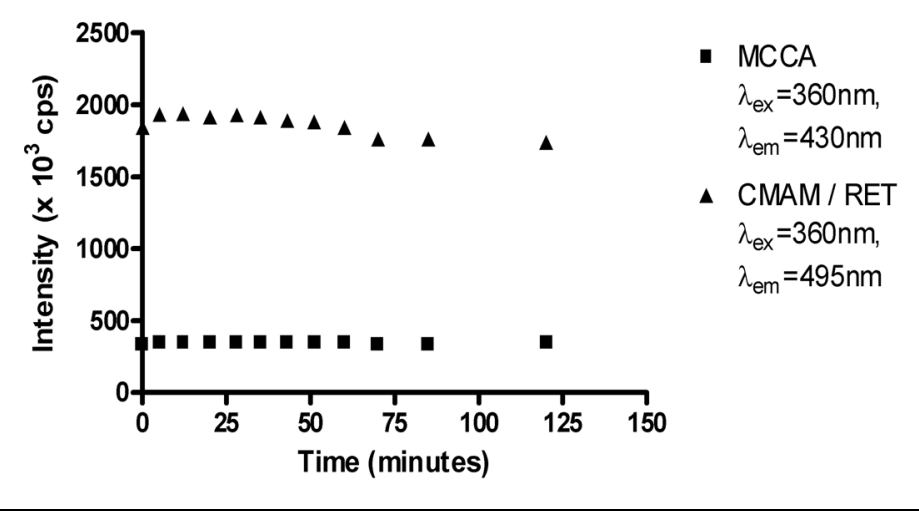

Figure S2: Dye 4 is stable in human blood plasma. If cleavage takes place, a decrease of the CMAM emission at $495 \mathrm{~nm}$ combined with an increase of MCCA emission at $435 \mathrm{~nm}$ could be observed. The constant emission intensities indicate that no cleavage has taken place. 
Viscosity sensing range of 4 (Figure S3): In mixtures of methanol and ethylene glycol (viscosity up to $14 \mathrm{mPa}$ s) and glycerol and ethylene glycol (viscosity above $14 \mathrm{mPa}$ ), dye $\mathbf{4}$ closely follows the power-law relationship stipulated by Equation 1 over a factor of 400 .

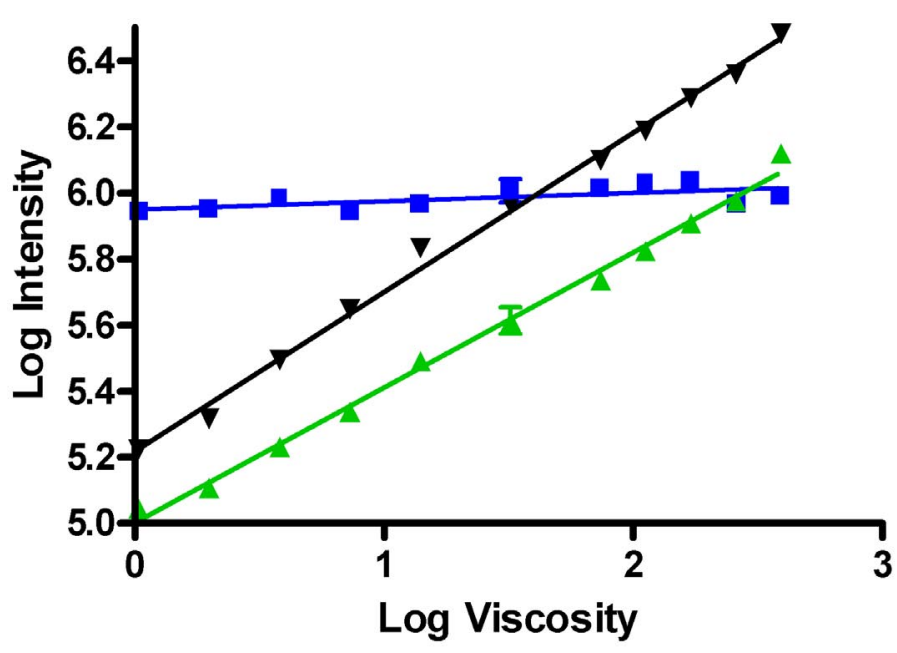

- MCCA, $\lambda_{\mathrm{ex}}=364 \mathrm{~nm}$

$\triangle \mathrm{CMAM} / \mathrm{RET}, \lambda_{\mathrm{ex}}=364 \mathrm{~nm}$

$\checkmark \mathrm{CMAM}, \lambda_{\mathrm{ex}}=440 \mathrm{~nm}$

Figure S3: Determination of the range of viscosity sensitivity. Since viscosity and intensity are related through a power-law relationship, data points of intensity over viscosity will lie on a straight line in a double-logarithmic scale. This power-law relationship is maintained from $1 \mathrm{mPa}$ $\mathrm{s}$ to $396 \mathrm{mPa}$ s, covering almost three orders of magnitude. Data points show average $\pm \mathrm{SD}$ of $\mathrm{n}=3$ independent experiments. Exponents were $\mathrm{x}=0.41\left(\mathrm{R}^{2}=0.99, \mathrm{P}<0.0001\right)$ for the RET peak and $\mathrm{x}=0.48\left(\mathrm{R}^{2}=0.99, \mathrm{P}<0.0001\right)$ for direct CMAM excitation. 
General Techniques. All reagents were commercially obtained (Aldrich, Acros) at highest commercial quality and used without further purification except where noted. Yields refer to chromatographically and spectroscopically $\left({ }^{1} \mathrm{H}\right.$ NMR, ${ }^{13} \mathrm{C}$ NMR) homogeneous materials. Reactions were monitored by thin-layer chromatography (TLC) carried out on $0.25 \mathrm{~mm}$ E. Merck silica gel plates (60F-254) using UV light as the visualizing agent and $10 \%$ ethanolic phosphomolybdic acid (PMA) or p-anisaldehyde solution and heat as developing agents. E. Merck silica gel (60, particle size 0.040-0.063 mm) was used for flash chromatography. Preparative thin-layer chromatography separations were carried out on 0.25 or $0.50 \mathrm{~mm}$ E. Merck silica gel plates (60F-254). NMR spectra were recorded on Varian Mercury 400 and/or Unity $500 \mathrm{MHz}$ instruments and calibrated using the residual undeuterated solvent as an internal reference. The following abbreviations were used to explain the multiplicities: $\mathrm{s}=$ singlet, $\mathrm{d}=$ doublet, $\mathrm{t}=$ triplet, $\mathrm{q}=$ quartet, $\mathrm{m}=$ multiplet, $\mathrm{b}=$ broad. High resolution mass spectra $($ HRMS) were recorded on a VG 7070 HS mass spectrometer under chemical ionization (CI) conditions or on a VG ZAB-ZSE mass spectrometer under fast atom bombardment (FAB) conditions.

\section{Experimental procedures and data}

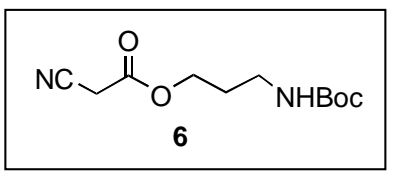

Ester 6: N-Boc-amino-propan-3-ol (2 g, 11.4 mmol), cyano acetic acid $(1.7 \mathrm{~g}, 20 \mathrm{mmol})$ and $\mathrm{EDC}(3.9 \mathrm{~g}, 20 \mathrm{mmol})$ were dissolved in $\mathrm{CH}_{2} \mathrm{Cl}_{2}$ $(40 \mathrm{~mL})$ and stirred for 6 hours at $25^{\circ} \mathrm{C}$. The solvent was removed on the rotary evaporator and the residue was applied to silica gel chromatography (30\% ether in hexanes) to afford $1.8 \mathrm{~g}$ of compound $6(81 \%)$. 6: colorless oil; $R_{f}=0.3$ (50\% ether); ${ }^{1} \mathrm{H}$ NMR (400 $\left.\mathrm{MHz}, \mathrm{CDCl}_{3}\right) \delta 4.25$ $(\mathrm{t}, \mathrm{J}=6.4 \mathrm{~Hz}, 2 \mathrm{H}), 3.48(\mathrm{~s}, 2 \mathrm{H}), 3.22(\mathrm{~m}, 2 \mathrm{H}), 1.86(\mathrm{~m}, 2 \mathrm{H}), 1.42(\mathrm{~s}, 9 \mathrm{H}) ;{ }^{13} \mathrm{C} \mathrm{NMR}(100 \mathrm{MHz}$, $\left.\mathrm{CDCl}_{3}\right) \delta 163.0,155.9,113.0,79.4,64.2,53.4,36.9,28.8,28.3,24.7$; HRMS, calcd for $\mathrm{C}_{11} \mathrm{H}_{18} \mathrm{~N}_{2} \mathrm{O}_{4}\left[\mathrm{M}+\mathrm{Na}^{+}\right]$265.1165, found: 265.1161 . 


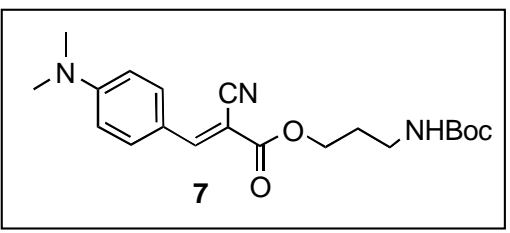

Carbamate 7: Ester 6 (1.5 g, $6.2 \mathrm{mmol})$, 4-dimethylamino benzaldehyde $(0.9 \mathrm{~g}, 6.2 \mathrm{mmol})$ and DBU $(0.9 \mathrm{~g}, 6.2 \mathrm{mmol})$, were dissolved in THF $(50 \mathrm{~mL})$ and stirred for 6 hours at $25^{\circ} \mathrm{C}$. The solvent was removed on the rotary evaporator and the residue was applied to silica gel chromatography (50\% ether in hexanes) to afford $1.9 \mathrm{~g}$ of compound 7 (85\%). 7: Yellow solid; $R_{f}=0.4$ (50\% ether); ${ }^{1} \mathrm{H}$ NMR $\left(400 \mathrm{MHz}, \mathrm{CDCl}_{3}\right) \delta 8.04$ (s, 1H), 7.90 (d, J= $8.8 \mathrm{~Hz}, 2 \mathrm{H}), 6.65(\mathrm{~d}, \mathrm{~J}=8.8 \mathrm{~Hz}, 2 \mathrm{H}), 4.32(\mathrm{t}, \mathrm{J}=6.4 \mathrm{~Hz}, 2 \mathrm{H}), 3.23(\mathrm{~m}, 2 \mathrm{H})$, $3.09(\mathrm{~s}, 6 \mathrm{H}), 1.91(\mathrm{~m}, 2 \mathrm{H}), 1.42(\mathrm{~s}, 9 \mathrm{H}) ;{ }^{13} \mathrm{C} \mathrm{NMR}\left(100 \mathrm{MHz}, \mathrm{CDCl}_{3}\right) \delta$ 164.3, 155.9, 154.7, 153.6, 119.1, 117.4, 111.4, 79.3, 63.3, 39.9, 37.3, 30.0, 28.3; HRMS, calcd for $\mathrm{C}_{20} \mathrm{H}_{27} \mathrm{~N}_{3} \mathrm{O}_{4}$ $\left[\mathrm{M}+\mathrm{Na}^{+}\right]$396.1900, found: 396.1893 .

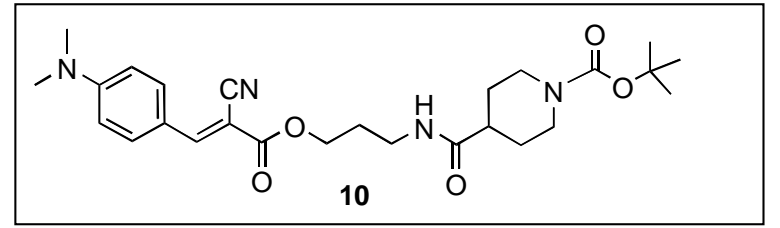

Carbamate 10: Carbamate $7(50 \mathrm{mg}, 0.13$ mmol) was stirred in a $2 \mathrm{~mL}$ of a $1 / 1$ mixture of TFA/ $\mathrm{CH}_{2} \mathrm{Cl}_{2}$ (containing $0.1 \%$ anisole) for 30 minutes at $25{ }^{\circ} \mathrm{C}$. The solvent was removed on the rotary evaporator then azeotroped three times with $5 \mathrm{~mL}$ of toluene. The residue was thoroughly dried on the high vacuum for 6 hours. The crude free amine $8(\sim 0.13 \mathrm{mmol}), N$-Bocisonipecotic acid (9) (30 mg, $0.13 \mathrm{mmol})$, EDC (31 mg, $016 \mathrm{mmol})$ and DIEA (25 mg, 0.2 mmol) were dissolved in DCM $(2 \mathrm{~mL})$ and stirred for 2 hours at $25{ }^{\circ} \mathrm{C}$. The solvent was diluted with $10 \mathrm{~mL}$ of $\mathrm{H}_{2} \mathrm{O}$ and extracted with $\mathrm{CH}_{2} \mathrm{Cl}_{2}(3 \times 5 \mathrm{~mL})$. The combined organics were dried over magnesium sulfate, the solvent was removed on the rotary evaporator and the residue was applied to silica gel chromatography (50\% ether in hexanes) to afford $55 \mathrm{mg}$ of compound $\mathbf{1 0}$ (85\%). 10: Yellow solid; $R_{f}=0.3$ (50\% ether); ${ }^{1} \mathrm{H}$ NMR (400 MHz, $\left.\mathrm{CDCl}_{3}\right) \delta 8.07(\mathrm{~s}, 1 \mathrm{H}), 7.92$ $(\mathrm{d}, \mathrm{J}=9.2 \mathrm{~Hz}, 2 \mathrm{H}), 6.71(\mathrm{~d}, \mathrm{~J}=9.2 \mathrm{~Hz}, 2 \mathrm{H}), 6.17$ (t, J= 5.6 Hz, 1H), $4.34(\mathrm{~d}, \mathrm{~J}=5.6 \mathrm{~Hz}, 2 \mathrm{H}), 4.11$ (bs, 2H), 3.41 (q, J= 6 Hz, 2H), $3.11(\mathrm{~s}, 6 \mathrm{H}), 2.74(\mathrm{bs}, 2 \mathrm{H}), 2.34$ (dt, J= 11.6, $3.6 \mathrm{~Hz}, 1 \mathrm{H}), 1.94$ $(\mathrm{m}, 2 \mathrm{H}), 1.84-1.73(\mathrm{~m}, 2 \mathrm{H}), 1.69-1.58(\mathrm{~m}, 2 \mathrm{H}), 1.44(\mathrm{~s}, 9 \mathrm{H}) ;{ }^{13} \mathrm{C} \mathrm{NMR}\left(100 \mathrm{MHz}, \mathrm{CDCl}_{3}\right) \delta$ 174.8, 164.3, 155.1, 154.6, 153.8, 134.2, 119.1, 118.0, 111.5, 92.5, 79.3, 64.5, 43.0, 40.0, 36.9, 28.6, 28.4; HRMS, calcd for $\mathrm{C}_{26} \mathrm{H}_{36} \mathrm{~N}_{4} \mathrm{O}_{5}\left[\mathrm{M}+\mathrm{Na}^{+}\right]$507.2584, found: 507.2584. 


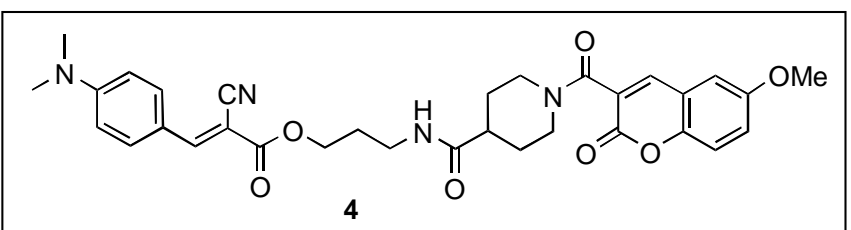

Amide 4: Carbamate 10 (40 $\mathrm{mg}, 0.08$ mmol) was stirred in $2 \mathrm{~mL}$ of a $1 / 1$ mixture of $\mathrm{TFA} / \mathrm{CH}_{2} \mathrm{Cl}_{2}$ (containing $0.1 \%$ anisole) for 30 minutes at $25{ }^{\circ} \mathrm{C}$. The solvent was removed on the rotary evaporator then azeotroped three times with $5 \mathrm{~mL}$ of toluene. The residue was thoroughly dried on the high vacuum for 6 hours. The crude free amine 11 ( $0.08 \mathrm{mmol}), 7$ methoxycoumarin-3-carboxylic acid N-succinimidyl ester 12 (25 mg, 0.08 mmol) and DIEA (20 $\mathrm{mg}, 0.15 \mathrm{mmol})$ were dissolved in $\mathrm{CH}_{2} \mathrm{Cl}_{2}(2 \mathrm{~mL})$ and stirred for 2 hours at $25{ }^{\circ} \mathrm{C}$. The solvent was diluted with $10 \mathrm{~mL}$ of $\mathrm{H}_{2} \mathrm{O}$ and extracted with $\mathrm{CH}_{2} \mathrm{Cl}_{2}(5 \mathrm{~mL}, 3 \mathrm{x})$. The combined organics were dried over magnesium sulfate, the solvent was removed on the rotary evaporator and the residue was applied to silica gel chromatography (50\% ether in hexanes) to afford $41 \mathrm{mg}$ of compound 4 (87\%). 4: Red oil; $R_{f}=0.4$ (50\% ether); ${ }^{1} \mathrm{H}$ NMR $\left(400 \mathrm{MHz}, \mathrm{CDCl}_{3}\right) \delta 8.09$ (s, 1H), $7.93(\mathrm{~d}, \mathrm{~J}=8.8 \mathrm{~Hz}, 2 \mathrm{H}), 7.87(\mathrm{~s}, 1 \mathrm{H}), 7.43(\mathrm{~d}, \mathrm{~J}=8.8 \mathrm{~Hz}, 1 \mathrm{H}), 6.88(\mathrm{dd}, \mathrm{J}=8,2 \mathrm{~Hz}, 1 \mathrm{H})$, $6.81(\mathrm{~d}, \mathrm{~J}=2.4 \mathrm{~Hz}, 1 \mathrm{H}), 6.71(\mathrm{~d}, \mathrm{~J}=9.2 \mathrm{~Hz}, 2 \mathrm{H}), 6.26(\mathrm{t}, \mathrm{J}=5.6 \mathrm{~Hz}, 1 \mathrm{H}), 4.67(\mathrm{~d}, \mathrm{~J}=13.6 \mathrm{~Hz}$ $1 \mathrm{H}), 4.37(\mathrm{t}, \mathrm{J}=4.8 \mathrm{~Hz}, 2 \mathrm{H}), 3.89(\mathrm{~s}, 3 \mathrm{H}), 3.67$ (d, J=12.8 Hz, 1H), 3.44 (q, J=6 Hz, 2H), 3.22 $(\mathrm{m}, 1 \mathrm{H}), 3.13(\mathrm{~s}, 6 \mathrm{H}), 2.90(\mathrm{~m}, 1 \mathrm{H}), 2.54(\mathrm{~m}, 1 \mathrm{H}), 1.91(\mathrm{~m}, 3 \mathrm{H}), 1.86-1.70(\mathrm{~m}, 3 \mathrm{H}) ;{ }^{13} \mathrm{C} \mathrm{NMR}$ $\left(100 \mathrm{MHz}, \mathrm{CDCl}_{3}\right) \delta 174.3,164.4,163.8,163.6,158.3,156.1,155.2,153.9,151.9,143.2,134.3$, 131.6, 129.6, 121.6, 119.1, 118.2, 113.2, 112.0, 111.6, 100.6, 92.6, 65.0, 55.9, 48.8, 42.6, 41.4, 40.1, 37.9, 28.5, 28.4; HRMS, calcd for $\mathrm{C}_{32} \mathrm{H}_{34} \mathrm{~N}_{4} \mathrm{O}_{7}\left[\mathrm{M}+\mathrm{Na}^{+}\right]$609.2326, found: 609.2319. 


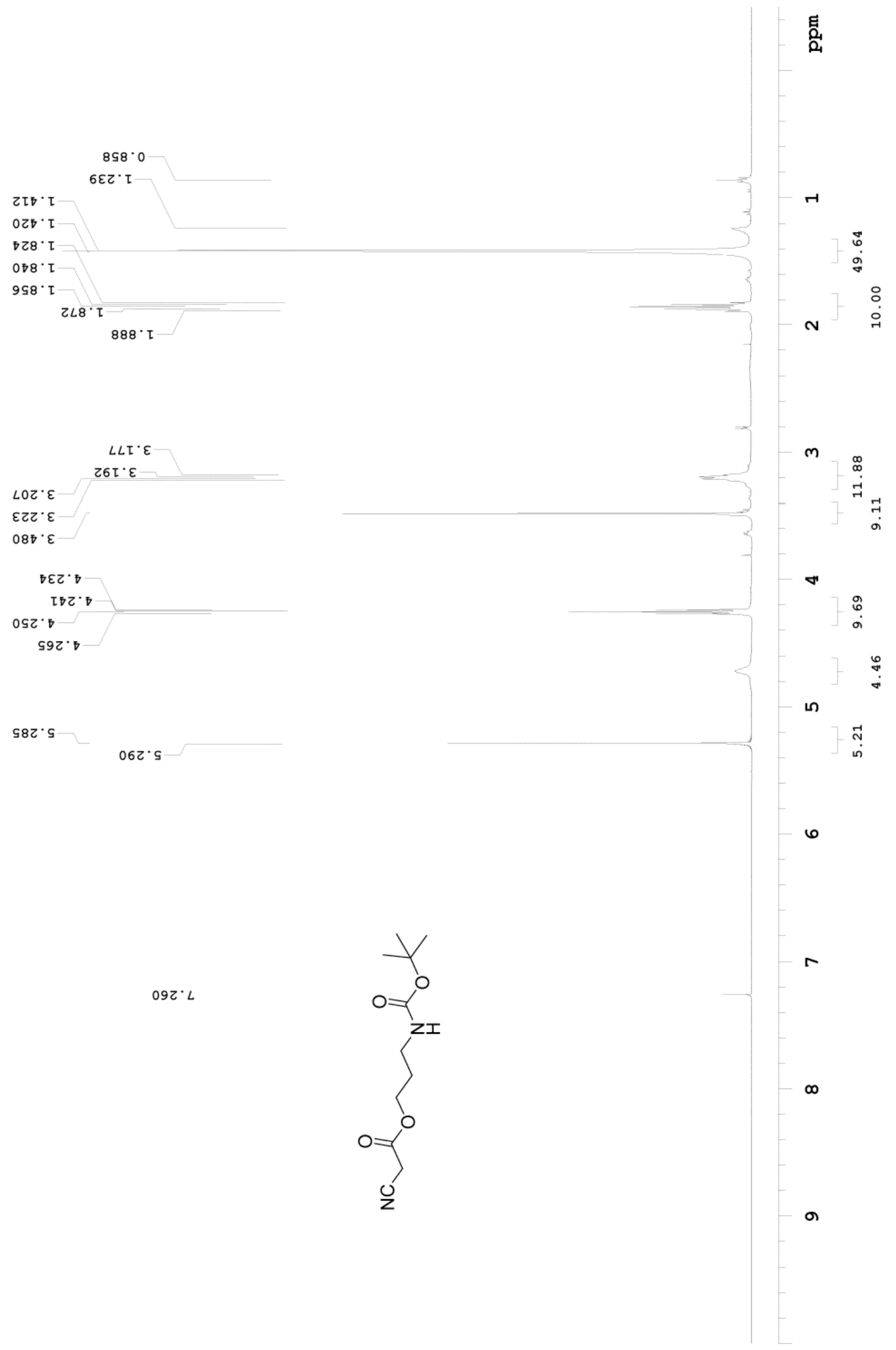




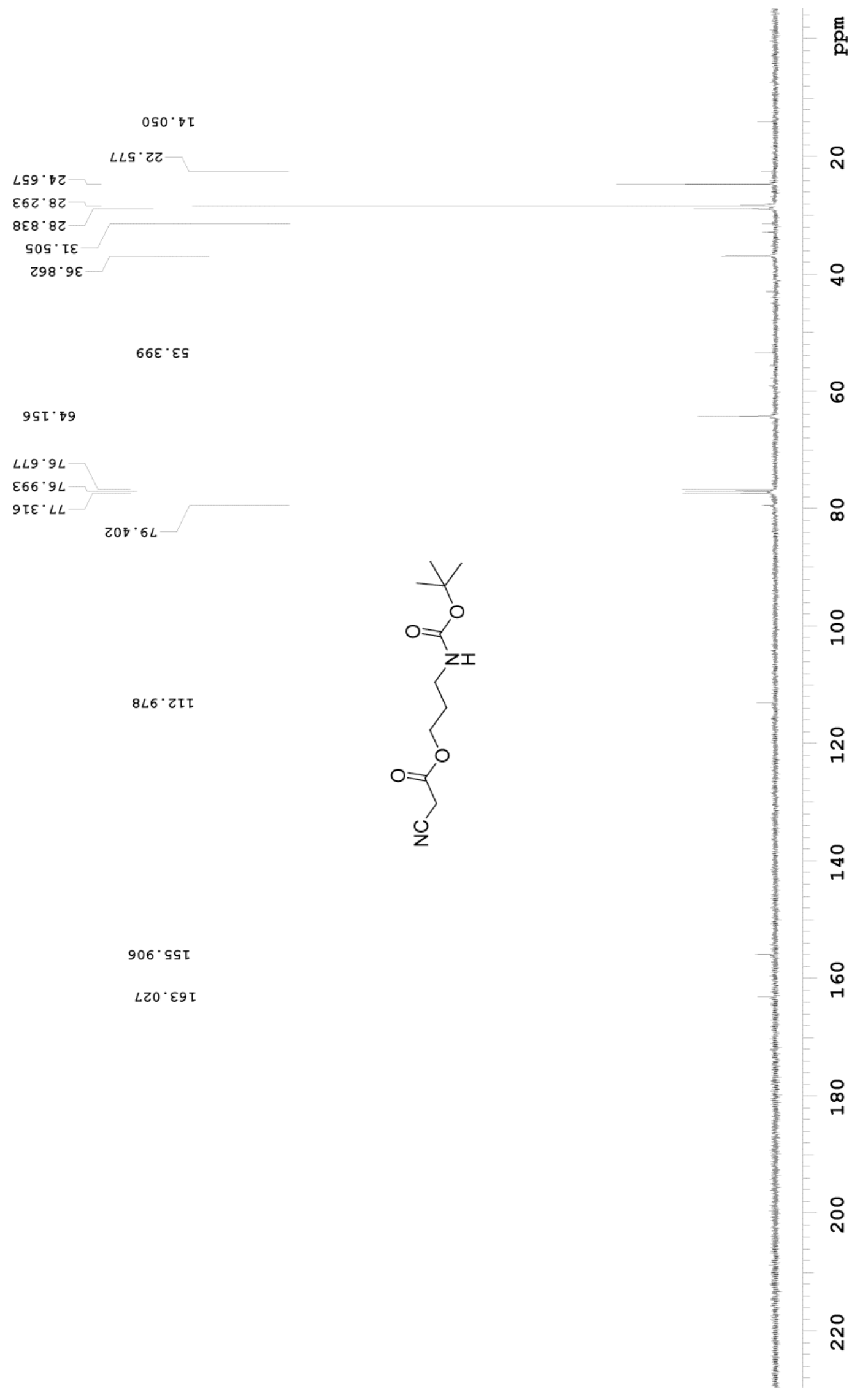




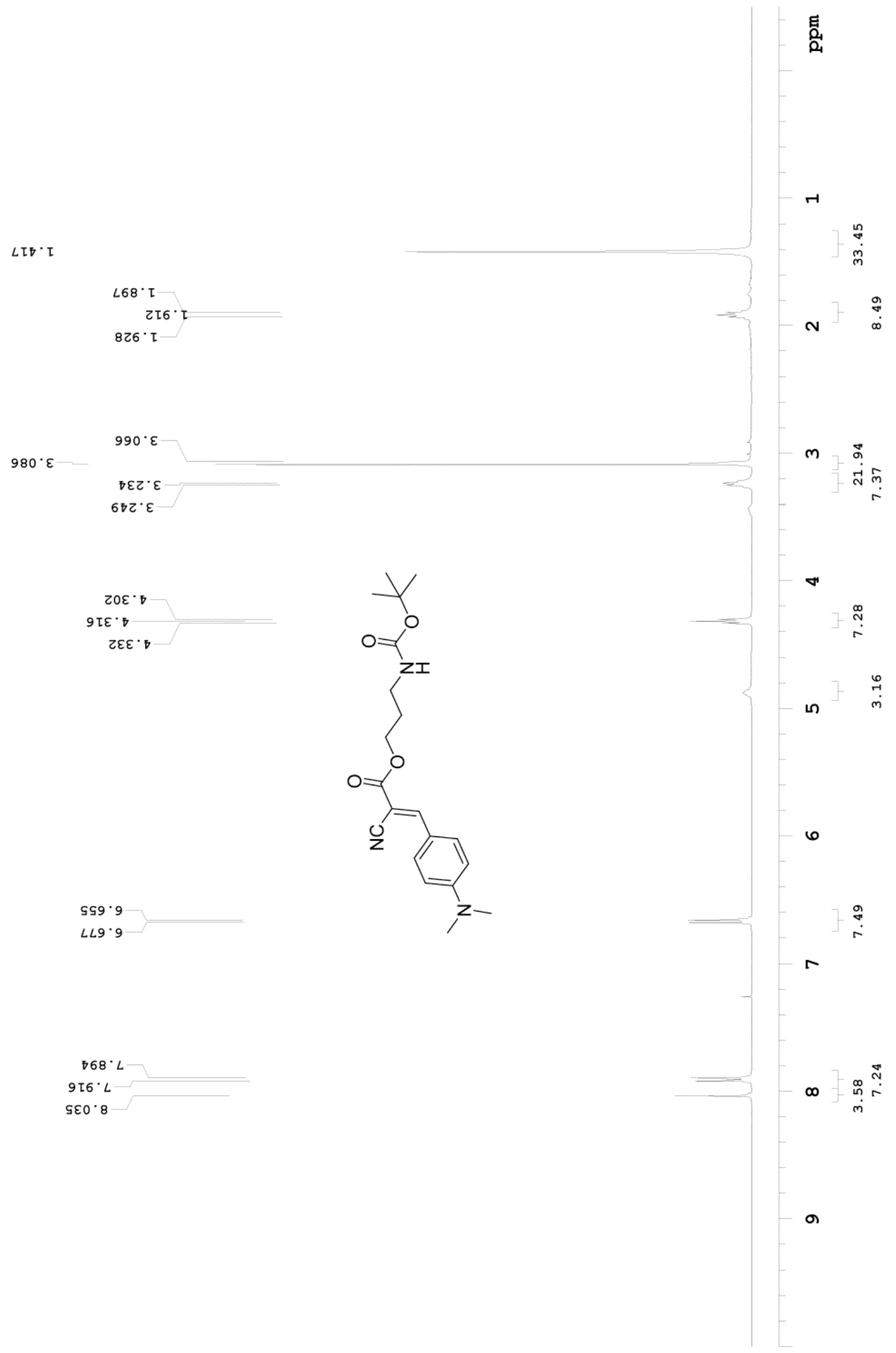



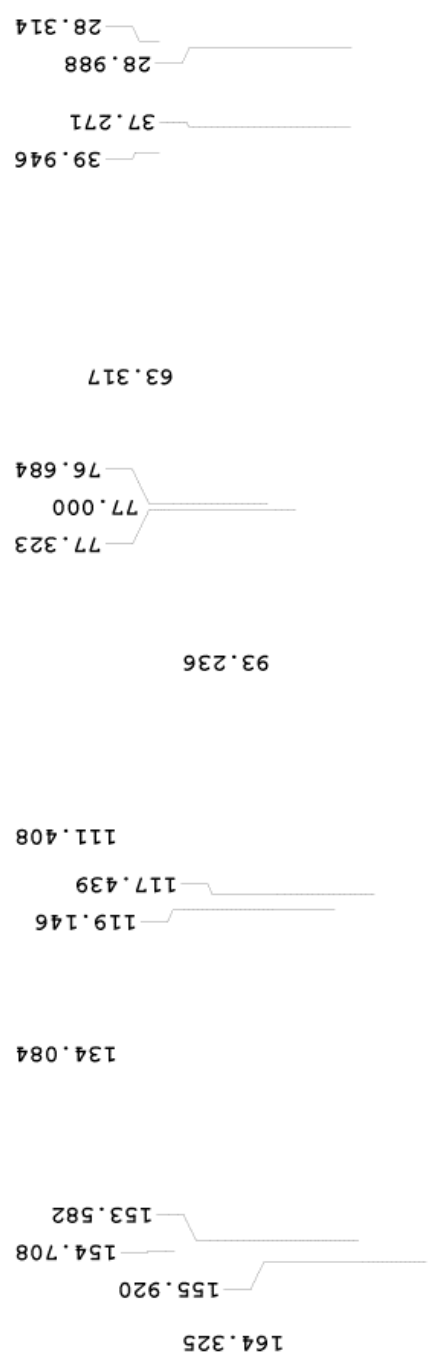

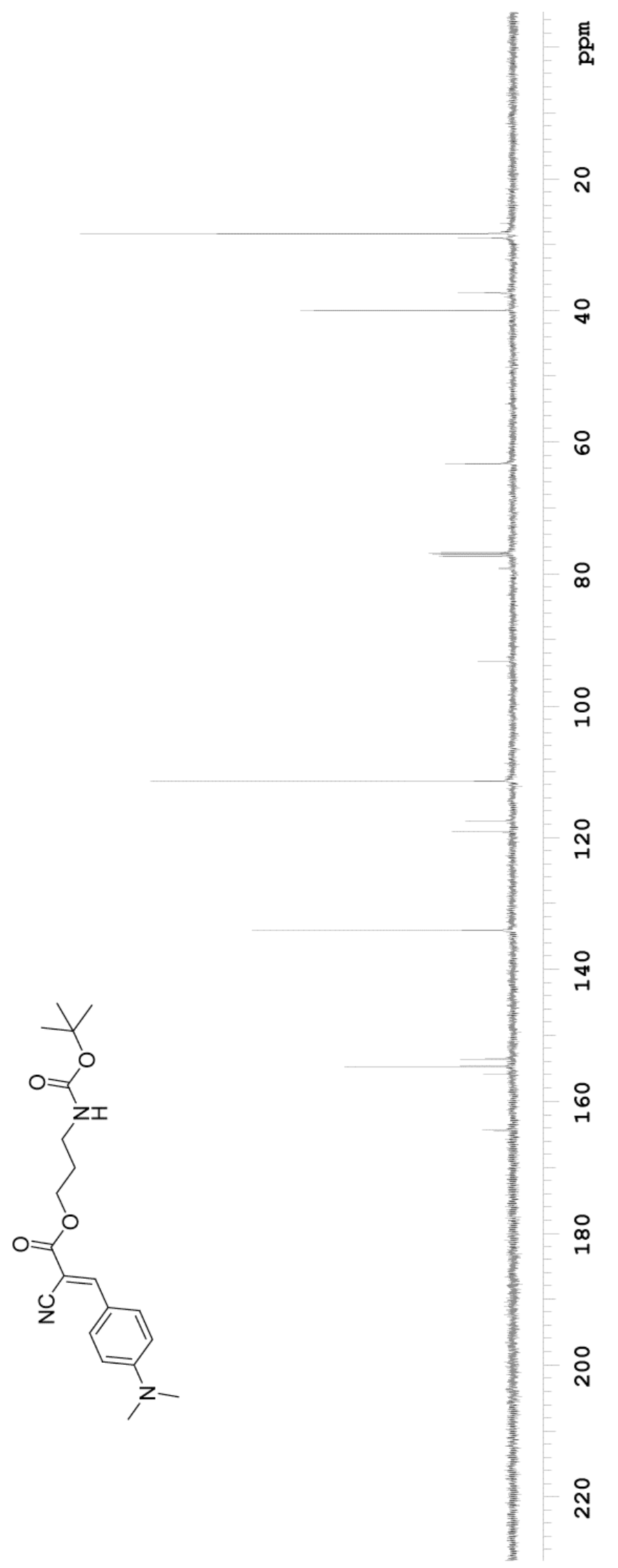




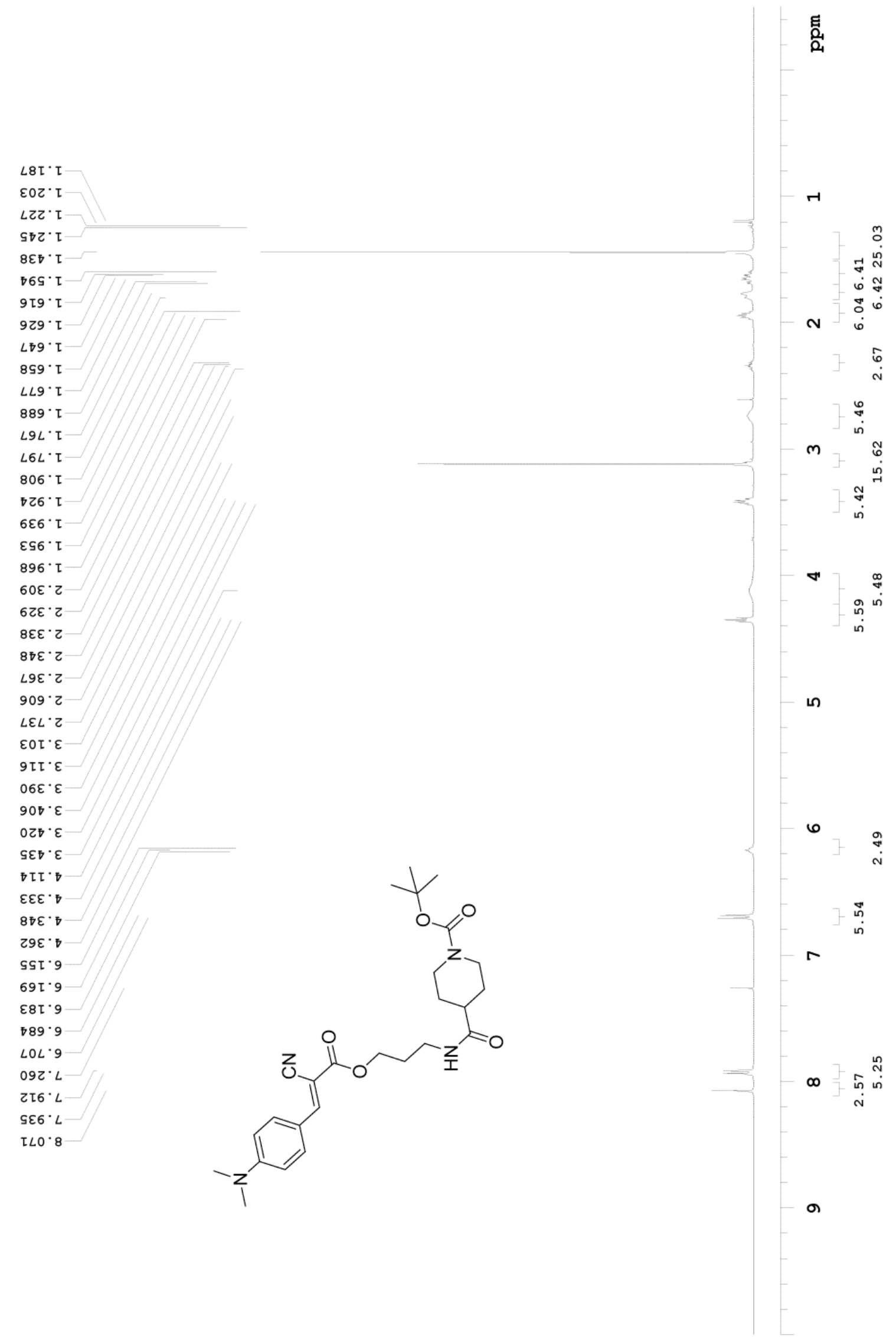




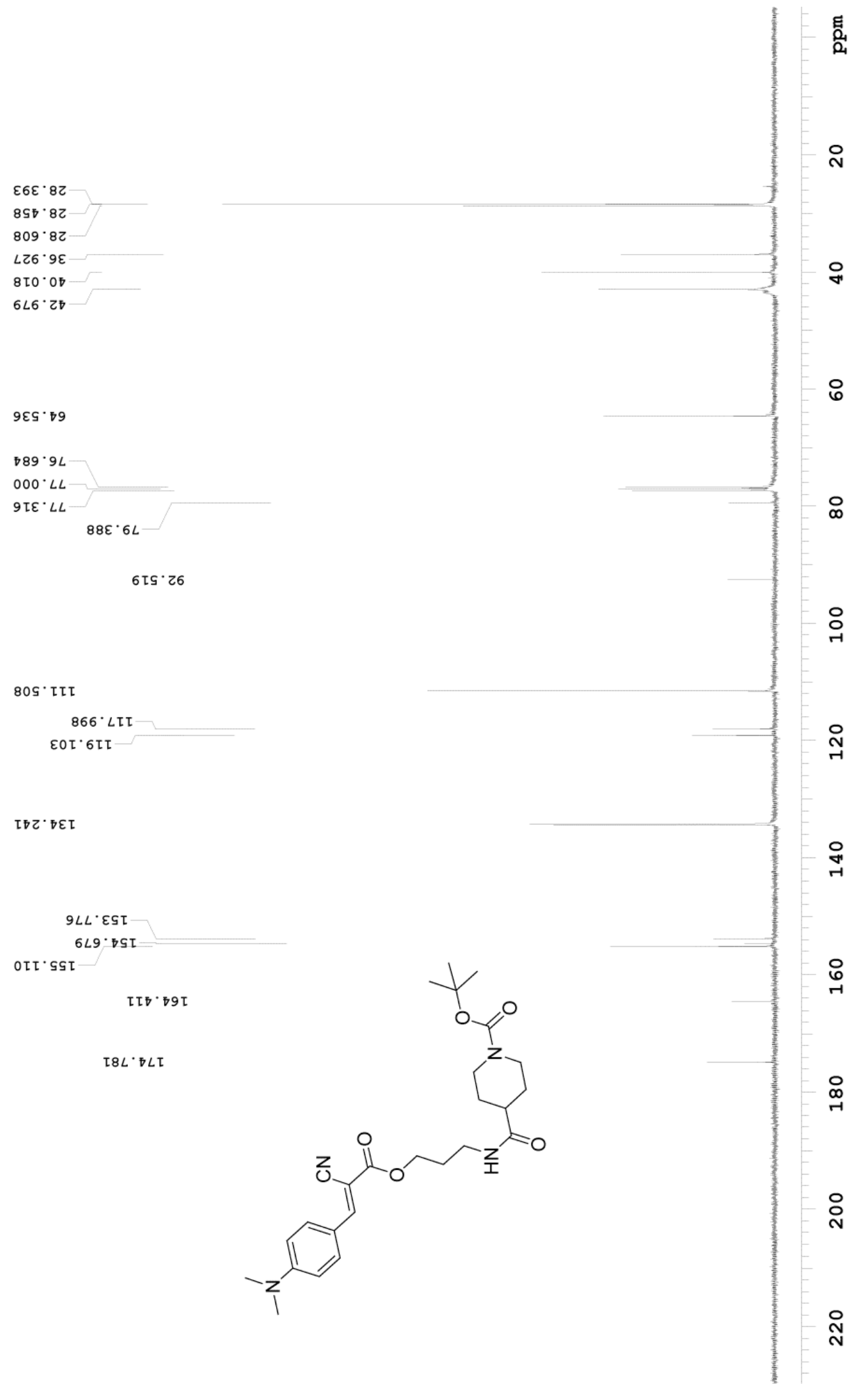




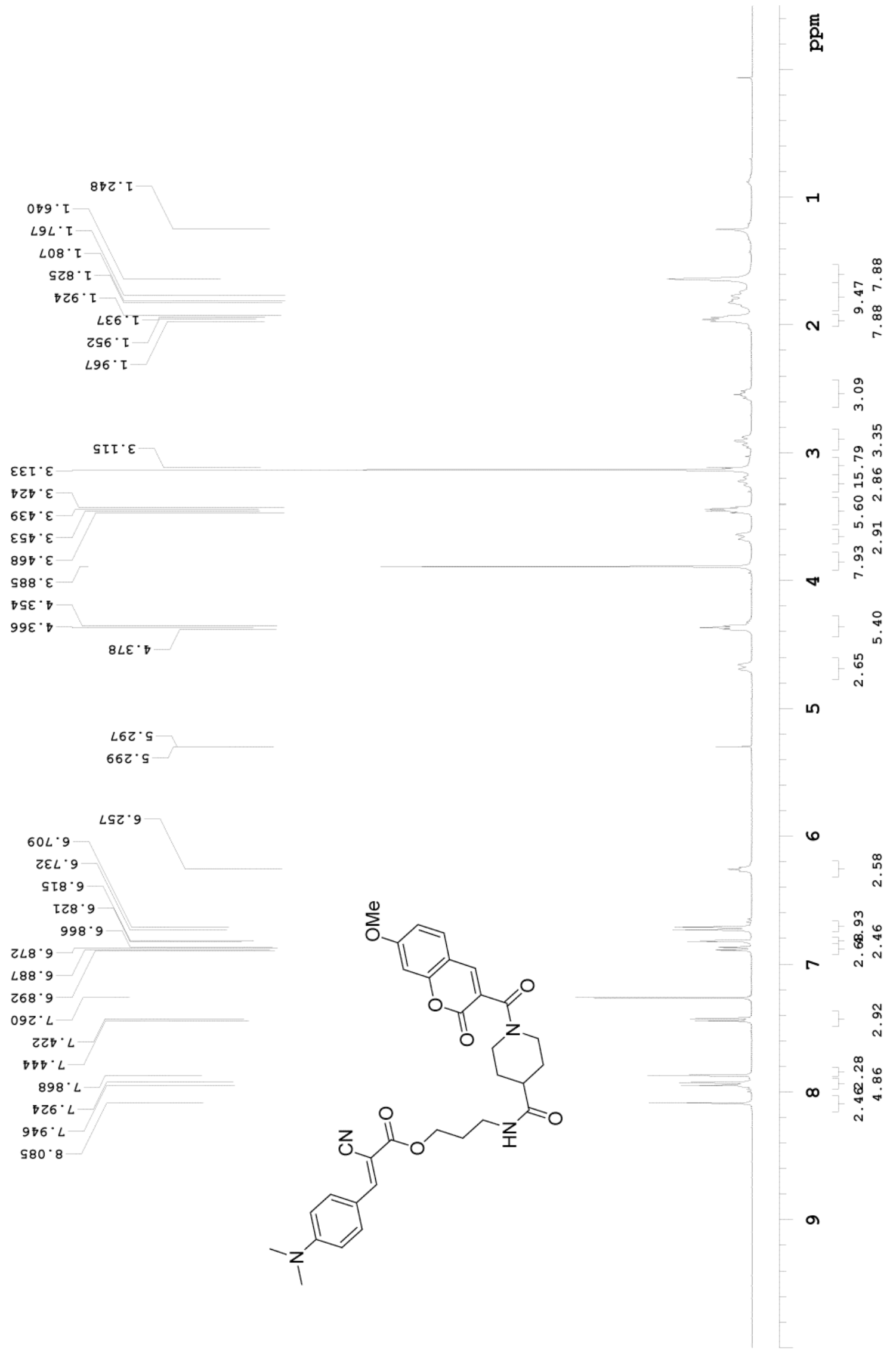




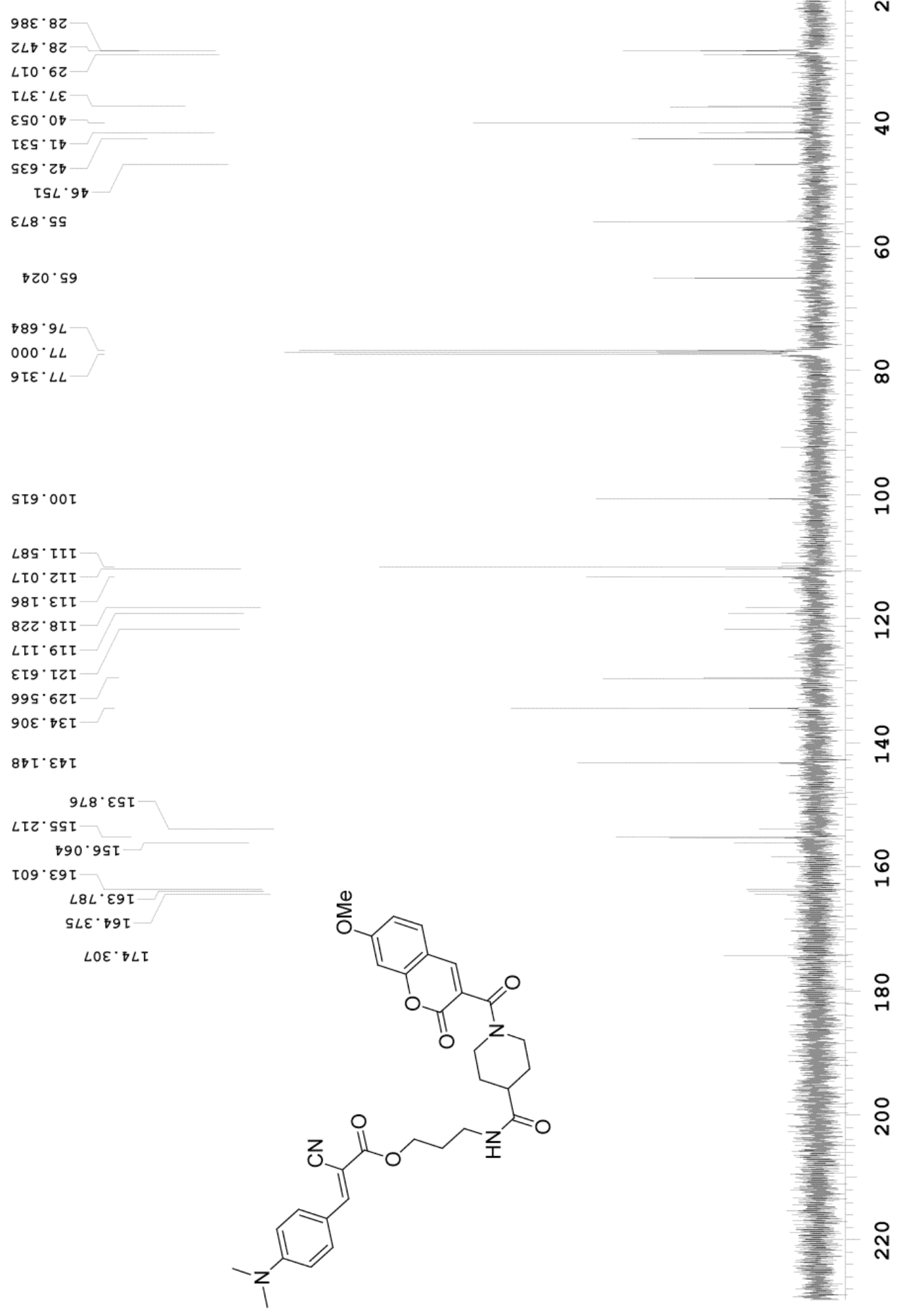

